\title{
NARATIV O BITKI KOD DUBICE 1513. GODINE IZ ŽIVOTOPISA PETRA BERISLAVIĆA FIKCIONALNA JE PRIČA
}

Miroslav PALAMETA

Filozofski fakultet u Splitu

Radovanova 13

HR - 21000 Split

E-pošta: miropal@yahoo.it
UDK 82:176.8]"16" 821.163.42-94.09 Mrnavić I.T.

Izvorni znanstveni rad Primljeno: 3. travnja 2015 Prihvaćeno: 27. lipnja 2015

Sažetak

Jedna od najpoznatijih afera u povijesti hrvatske književnosti vezana je za latinski životopis biskupa i bana Petra Berislavića (?-1520.) koji je pod naslovom Vita Petri Berislavi Bosnensis, episcopi Vesprimensis, Dalmatiae, Croatiae, Slavoniae, Bosnnaeque bani, (Venecija, 1620.) objavio Ivan Tomko Mrnavić (1580.-1637.), a izazvana je optužbom prirodoslovca Alberta Fortisa (1741.-1803.) u putopisu Viaggio in Dalmazia, (Venecija, 1773.) da je to djelo gotovo doslovni plagijat stotinjak godina prije napisanoga istoimenog djela Antuna Vrančića (1504.-1573.), čiji je izvornik navodno on našao u Šibeniku, u obiteljskom arhivu Draganića-Vrančića. Premda nitko ni prije ni poslije nije vidio sporni rukopis, niti iznio bilo kakav valjan dokaz o njegovu postojanju, Fortisovu optužnicu prihvatila je hrvatska znanstvena javnost, pa je ona uza stanovite preinake ostala na snazi sve do danas. Ćlanak Narativ o bitki kod Dubice 1513., koji je samo jedno poglavlje u opsežnom rukopisu o Mrnavićevu autorstvu Životopisa Petra Berislavića, prilagođen je za samostalno objavljivanje. U njemu se pokazuje kako je 
jezgro priče o spomenutoj bitki pod Dubicom nastalo mnogo godina poslije smrti Antuna Vrančića, pa ga on nije mogao ni oblikovati.

Polazeći od općeprihvaćenoga stajališta da Antun Vrančić u svojim tekstovima operira vjerodostojnim povijesnim činjenicama, a da je Ivan Tomko Mrnavić u tom smislu poprilično nepouzdan, naratološkom bi se analizom reprezentativne cjeline iz Životopisa, koja govori o Bitki pod Dubicom 1513. nastojalo u radu odgovoriti na pitanje o autorstvu toga dijela teksta. Također bi se na tragu izučavanja faktografske priče ta cjelina promatrala u svjetlu relevantnih povijesnih izvora i povjesničarskih diskursa.

Ključne riječi: fikcija, narativ, falsifikacija, plagijat, Mrnavić, Vrančić, Berislavić, Dubica.

\section{Uvod}

Priča o pobjedi Petra Berislavića nad brojčano nadmoćnom turskom vojskom kod Dubice 1513. godine sročena je u Životopisu kao zaokružena epizoda koja svojim opsegom od deset stranica teksta (VPB, str. 20-30) ${ }^{1}$ oponira ostalim sadržajima u kontekstu, ${ }^{2}$ odnosno fragmentarnosti i kratkoći povijesnih dokumenata izvan njega. Zato, posebice zbog naravi vlastitoga ustroja, nudi se ona preispitivanju poglavito na razini pripadnosti historiografskom ili literarnom diskursu. Stoga je iznimno važno prepoznati koliko taj prikaz uvažava vjerodostojne povijesne izvore, a u kojoj je mjeri plod piščeve imaginacije.

Ipak, prije toga valjalo bi makar naznačiti recepciju Fortisove optužbe među znanstvenicima koji su se ozbiljnije zanimali Životopisom Petra Berislavića. Dakle, nakon Fortisove optužbe javio se makarski kanonik Ivan Pavlović Lučić i stao u obranu tada cijenjenoga pisca Ivana Tomke Mrnavića, pa se o tome nije govorilo tijekom sljedećih osamdesetak godina. Ali, nakon što je Vallentineli u Bibliografiji Dalmacije i Crne Gore ${ }^{3}$

1 Skraćenica za Vita Petri Berislavi i paginaciju prvotiska iz 1620. godine.

2 Životopis započinje prikazom slavnoga podrijetla Petrovih predaka, bosanskih plemića, njegovim djetinjstvom s majkom u Trogiru, a nastavlja se prikazom dječaštva i mladosti kod slavonskih Berislavića i uvođenjem u društveni i politički život s delikatnim i uspješnim diplomatskim misijama koje su mu priskrbile ugled, javno priznanje i biskupsku čast u Vesprimu, a onda imenovanje za vranskoga priora i hrvatskoga bana. Nakon tih dvadesetak stranica, posebna je cjelina o čuvenoj povijesnoj pobjedi nad četiri puta brojnijim turskim snagama kod Dubice. U nastavku Životopisa nekoliko autentičnih vladarskih pisama, uglavnom upućenih banu Berislaviću, stožerna su uporišta kompozicije koja završava epizodom o Banovoj smrti 1520. i etosom, neizostavnim u tradicionalnim biografijama.

3 Giuseppe Vallentineli, Bibliografia della Dalmazia e del Montenegro, Zagabria, 1855. str. 166-167. 
objavio uz natuknicu Vita Petri Berislavi Fortisovu optužbu Mrnavića za plagijat i kratku obranu makarskoga kanonika Lučića, ${ }^{4}$ mađarski priređivač Vrančićevih djela Laszlo Szalay dobavio je prijepis Životopisa iz Marciane i objavio ga među Vrančićevim djelima, ali pod Mrnavićevim imenom, s kratkom opaskom koja opovrgava Fortisovu optužbu. ${ }^{5}$ Ivan Kukuljević petnaestak godina nakon toga kritizirao je Fortisa i autorstvo Berislavićeva Životopisa pripisao Mrnaviću, pokazujući između ostaloga kako je cijeli početak o starijim predcima glavnoga junaka Mrnavićeva fikcionalna priča. ${ }^{6}$ Ar- min Pavić, oduševljen Fortisom, ipak je povjerovao u postojanje Vrančićeva predloška pa je pod dojmom Kukuljevićeve ekspertize samo redefinirao Fortisovu optužbu i oblikovao obrazac koji uglavnom do danas vrijedi. ${ }^{7}$ Klaiću je bez ikakve elaboracije bilo to kompromisno rješenje pa je smatrao kako je Mrnavić samo proširio Vrančićevu skicu Životopisa Petra Berislavića. ${ }^{8} \mathrm{Na}$ tim istim pozicijama Armina Pavića ostala je znanstvenica Tamara Tvrtković. U predgovoru prijevoda Berislavićeva Zivotopisa, koji je objavila 2008. godine, pokazala je da je Mrnavićeva tvrdanja iz predgovora Životopisu, gdje spominje Antuna

4 Ivan Pavlović Lučić, "Praefatio ad lectorem", u: Ivan Tomko Mrnavić, Vita S. Sabbae Abbatis Stephani Nemaniae Rasciae regis filii, Mleci, 1789., str. 12-13.

5 "Ebből látni való, hogy az impudentissimo plagio elnevezés nincsen helyén, mert Marnavics világosan irja: Petri res gestas ex diversis authoribus, imprimis vero... Antonii Verantii... scriptis carptim excerptas teneo, s mert munkájának irásmódja, átalán véve, lényegesen eltér a Verancsicsétól. Annyi mindazáltal nem vonathatván kétségbe, hogy a mi Antalunk irományai föfö forrásul szolgáltak Marnavicsnak, s hogy Beriszló Péter életirása a Verancsicsoknak, mint Beriszló es Statileo rokonainak viszonyaikra is tanúságos világot vet: a szóban forgó dolgozat ideiktatását elégségesen igazoltnak itélem." Szalay LÁszLó, Verancsics Antal összes munkái, Monumenta Hungariae historica, svezak. III., Pešta, 1857., str. XIV. "Iz toga se vidi da naziv impudentissimo plagio nije primjeren, budući da Marnavić jasno piše: Petri res gestas ex diversis authoribus, imprimis vero... Antonii Verantii... scriptis carptim excerptas teneo, a i zbog toga što se stil njegova rada, gledano u cjelini, bitno razlikuje od Vrančičeva stila. Ipak se zbog toga ne može dovesti u pitanje, da su spisi našeg Antala poslužili kao glavni izvor Mrnaviću, te da životopis Petra Berislavića baca poučno svjetlo na rodbinske odnose Vrančičevih kao i Berislavića i Statilića: stoga smatram dovoljno opravdanim da se ovamo uvrsti spomenuti spis." (Preveo s mađarskoga jezika Mihály Szentmártoni, S.J.).

6 Ivan Kukuljević Sakcinski, Književnici u Hrvatah iz prve polovine VXII. vieka sovu stranu Velebita, Zagreb, 1869., str. 106-109.

7 "Fortis, mletački abbé, učaše o Mrnaviću mletačke spomenike, koji prema piscu, kao što vidjesmo, sigurno da ne bjehu nepristrani, s toga nam Fortisovu tvrdnju treba stegnuti ovako: Mrnavić se pišući vitam (!) Berislavi poslužio istoimenim Vrančićevim spisom, koji je upravo većim dijelom do slovca prepisao." Armin Pavić, Ivan Tomko Mrnavić, Rad JAZU, 33, Zagreb, 1875., str. 77.

8 "Petar Berislavić, pobjednik u boju kod Dubice, spada među najodličnije muževe hrvatskog naroda na osvitku šesnaestog stoljeća. Djela je njegova opisao mlađi rođak njegov Antun Vrančić, potonji nadbiskup ostrogonski (†1573.): Vrančićeve pak bilješke upotrijebio je u sedamnaestom stoljeću Ivan Tomko Mrnavić za svoj opširni životopis." Vjekoslav Klaić, Povijest Hrvata, Treće doba: Vladanje kraljeva iz raznih porodica (1301-1525). Od gubitka Dalmacije do Matije Korvina (1409-1457). Doba kralja Matijaša Korvina i Jagelovića (1458-1526), Matica hrvatska, Zagreb, 1974., str. 306. 
Vrančića kao svoj glavni izvor, ipak točna. No, pri toj tvrdnji smatra kako se ona odnosi na onaj rukopis koji je tobože u Šibeniku vidio Alberto Fortis, premda je u tom istom radu središnji doprinos usporedba Vrančićeve anegdote o trojici ugarskih velikaša iz putopisa Iter Buda Hadrianopolim $s$ njezinom jedva izmijenjenom inačicom koju je Mrnavić unio u Životopis. Da autorica Vrančića smatra glavnim autorom vidi se i po njezinoj prosudbi da je on, ili njegov ujak Ivan Statilić, oblikovao posve negativan lik Petra Kružića, jer su njih dvojica bili pristaše Ivana Zapolje, a Kružić je u službi cara Ferdinanda!' Mrnavića očito smatra patološkim falsifikatorom, jer je iznenađena $\mathrm{u}$ tom istom članku činjenicom da je Mrnavić u Životopis uvrstio ipak autentična papinska i kraljevska pisma banu Berislaviću, a da u njih nije ništa dodao ili ispuštao. $U$ tom svjetlu valjalo bi shvatiti i njezin konačni zaključak o toj problematici: "Očito je, dakle, da se Mrnavić prilikom sastavljanja Berislavićeva životopisa poslužio Vrančićevim spisom (što uostalom nije ni zanijekao), ali jednako tako da je u životopis unio i neke elemente koji i njega samog povezuju sa slavnom obitelji Berislavić."10
U svakom slučaju, nitko od znanstvenika koji su se bavili Životopisom nije preispitivao epizodu o bitki pod Dubicom iz 1513. Jedino je Klaić u navedenom tekstu preuzeo Mrnavićev narativ, smatrajući da je Vrančićev, ali je njezinu prostornu podlogu pomaknuo niz Unu prema Kostajnici. Kako ta epizoda zauzima svojim opsegom sedminu cijeloga Životopisa, a prikazuje najpoznatiji i u povijesti potvrđeni događaj, rezultati njezina preispitivanja mogu biti relevantni za procjenu je li postojao Vrančićev predložak ili je on samo Fortisova izmišljotina. Naime, ako je taj rukopis postojao, Vrančić bi o toj bitki, kao najvažnijoj Berislavićevoj pobjedi nad Turcima, morao nešto reći. Utvrdi li se da se ta opsežna epizoda oslanja na neke druge izvore koji su se pojavili nakon Vrančićeve smrti, onda su procjene Fortisovih sljedbenika pod velikim znakom pitanja.

\section{1. Činjenično i izmišljeno na istoj razini}

U gorljivom nastojanju da svom junaku prida što veći značaj, već na samom početku epizode, pisac mu je uz postojeće naslove i priznanja pripisivao i one koje on nije tada imao ili

9 Kružić je u Životopisu oblikovan kao negativan lik, oponentan glavnom junaku. Stoga je pisac za njegovu ulogu posve prestilizirao i premotivirao Istvánffyjev tekst o turskom zauzeću Klisa 1537. (Miknós Istvánffy, Nicolai Isthuanfi Pannonii Historiarum de rebus hungaricis libri XXXIV, nunc primum in lucem editi, Coloniae Agrippinae, 1622., str. 130). Ni Perojević to nije primijetio i ostao je u uvjerenju da povijesni izvori o tome ne govore (Marko Perojević, Petar Kružić - kapetan i knez grada Klisa, Matica hrvatska, Zagreb, 1931.). Prema tome, posve je izvjesno kako je i taj dio teksta mogao sastaviti samo Mrnavić, a nikako Antun Vrančić ili Ivan Statilić.

10 Tamara Tvrtković, "Vita Petri Berislavi, Ivan Tomko Mrnavić i Antun Vrančić", u: Ivan Tomko Mrnavić, Vita Petri Berislavi - Životopis Petra Berislavića, Hrvatski institut za povijest - Muzej grada Trogira, Zagreb - Trogir, 2008., str. 15-21. 
nikada nije nosio. Berislavić je u tom trenutku zapravo imenovan samo podbanom palatina i bana Emerika Perényja, a njegovo proglašenje opatom Porna, što su pratili značajni dohodci i ugledna titula koju je sredinom stoljeća nosio Antun Vrančić, a u vrijeme objavljivanja Životopisa njegov adresant Juraj Drašković, nije do sada ni jednom egzaktnom potvrdom zajamčeno. Također, imenovanje Berislavića jajačkim banom posve je izmišljen podatak. Kumulacija naslova, koji bi po retoričkom načelu trebali stajati u reciprocitetu sa stvarnom moći i ugledom u društvu, u Životopisu označuju uvod u zbivanja i događaje u kojima će junak opravdati polučene položaje i zasjati svojim vrlinama, premda se iz historiografske perspektive o spomenutim potankostima drukčije dade govoriti. Zanemare li se u tom slučaju druge nepreciznosti kao njegovo ređenje za biskupa vesprimskoga mnogo ranije od 1512., kad se prvi put i spominje $s$ tim crkvenim položajem u relevantnim izvorima, spomenuti primjeri dovoljno su znakoviti jer se u Životopisu dovode $\mathrm{u}$ istu razinu podatci izvedeni iz vjerodostojnih dokumenata s onima što ih je pisac izmislio. ${ }^{11}$

\section{Domišljeni borbeni uspjesi}

Kako pripovjedač nije spomenuo prije tako značajne bitke niti na jednom mjestu bilo kakvo borbeno iskustvo novoga bana, on je domislio i pripisao mu cijeli niz pobjeda i učinkovitih djelovanja duboko u neprijateljskom teritoriju nakon carskoga ukaza da ode u Hrvatsku. Tako mu je u svom pripovijedanju osigurao ratničku slavu i kod podanika ugarskoga kralja i poštovanje samih Turaka, čime je motivirao i smirivanje na granici i veliku kasniju pobjedu. Motiv o banovu preodijevanju i izviđanju po neprijateljskim mjestima koje je poslije napadao, prenoseći ratna djelovanja na protivnikov teren, kao izrazit pripovjedni i avanturistički topos dovoljno upućuje da su spomenuti događaji samo narativna konstrukcija koju vjerodostojni povijesni dokumenti samo učvršćuju.

Prema službenim izvješćima mletačkoga izaslanika u Budimu, ban Berislavić je tek početkom lipnja 1513. dobio nalog da $s$ vojskom ide $\mathrm{u} \mathrm{Hr}$ vatsku, jer su neku utvrdu zauzeli Turci, ${ }^{12}$ a 21. srpnja još je u Budimu i kod njega u kurtoaznom oproštajnom posjetu, odakle odlazi na svoje odredište u Hrvatsku, gdje neprijatelj i dalje prodire i zauzima kraljeve utvrde. ${ }^{13}$ Prema tome, kad su Turci napali sjeverne krajeve $s$ lijevu stranu Une, ban nije mogao biti zaokupljen popravcima utvrđenja u južnim krajevima, kako se u Životopisu tvrdi, niti je u tako kratkom vremenu mogao izviđati neprijateljski teritorij ili izvršiti

11 U stilskom smislu te izmišljene titulacije i dužnosti neodoljivo podsjećaju na one u Govoru na pogrebu Fausta Vrančića u kome ih Ivan Tomko Mrnavić pripisuje Faustovu slavnom pretku banu Berislaviću. U tom govoru dodijelio mu je prefekturu kraljevske tvrđave budimske, kvesturu transilvansku, titulu carskoga zapovjednika svih vojski ugarske krune, za što nema nikakve osnove. Ivan Tomko Mrnavić, Govor na pogrebu Fausta Vrančića, (prijevod s latinskog dr. Olga Perić), Gradska knjižnica "Juraj Šižgorić", Šibenik, 1993.

12 Marino Sanudo, I diarii, liber XVI., Venezia, 1501.-1503., str. 409.

13 Isto, str. 475. 
kakvo junačko djelo. U takve maštovite rekonstrukcije povijesti nije se ni $\mathrm{u}$ jednom svom tekstu upuštao Antun Vrančić, ali je u Mrnavićevim djelima takav postupak redovit i uobičajen.

\section{Parafraziranje Antuna Vrančića}

Nedvojbeno je da je povijesni Berislavić bio òbučen u ratničkom umijeću, ali pisac o tome nije znao pojedinosti, pa je svom literarnom junaku osigurao uvjerljivo literarno ratničko iskustvo i profilirao ga kao nositelja osobitih vrjednota pred veliku i slavnu pobjedu. $\mathrm{Na}$ toj ravni fikcionalnosti posebno je znakovit završetak toga uspješnog četovanja, kojim mu je osigurao ugled i kod protivnika i kod svojih sunarodnjaka: "Zaista, kad su Turci Petrovom hrabrošću svuda po Bosni i uz druge ugarske međaše bili potisnuti, odbijeni i otjerani, posavjetovali su se o tome $s$ kolikim bi najviše mobiliziranim snagama morali udariti na novog bana i provjeriti, razmišljaju li to stvarno Ugri obnoviti staru čvrstinu, zbog nemara velikaša polumrtvu od smrti uzvišenog Matijaša." ${ }^{14}$

U cijelom Životopisu nema mnogo tako jasnih primjera prožimanja $s$ povijesnim razmišljanjima Antuna Vrančića kao što je upravo istaknuti navod, koji postaje žarište sličnih reminiscencija u Životopisu. Ta je jezgrovita poanta izravni odraz njegove središnje misli iz Povijesti Ugara od početka propadanja kraljevstva (De rebus Hungarorum ab inclinatione regni) prema kojoj su "bahati aristokrati (...) zamrzili na kraljeve herojske odvažnosti" kao što je bio kralj Matijaš, i ugađajući samo svojim prohtjevima, skršili "onu silnu moć koja se barem petsto godina pronosila $\mathrm{kroz}$ sjajan rast ratničke vrline". ${ }^{15} \mathrm{U}$ tom je kontekstu Berislavić projektiran kao nositelj starih izgubljenih vrjednota, spreman da pobjedi triput jačega protivnika u bitki koja ubrzo slijedi, a Turci, kao kolektivni agens u Zivotopisu, na tom mjestu ne spremaju uobičajeni pljačkaški pohod, nego $s$ humanističkom radoznalošću na tragu upravo Vrančićevih razmišljanja namjeravaju to provjeriti. $U$ tome nema ni traga povjesničarskom diskursu. $\mathrm{Na}$ djelu je literarna imaginacija koja se održava i oblikuje na historijskoj tematskoj podlozi. Ona će oblikovati zapravo cijelu epizodu o bitki pod Dubicom, na što mogu posebno uputiti kratka i fragmentarna povijesna svjedočanstva.

\section{Najranija izvješća o bitki pod Dubicom i narativ iz Životopisa}

Najranija vijest o velikoj banovoj pobjedi sačuvana je u kratkom pismu koje je nekoliko dana poslije bitke napisao mletačkom duždu knez Ivan s Krbave. I sam sudionik u tim zbivanjima javlja kako je "prečasni Petar Berislavić, ban Hrvatske, pobijedio pašu, a u tom boju tri je tisuće Tura-

14 "Verum enimvero cum Turcae pasim per Bosnam aliosque hungaricos limites virtute Petri reprimerentur, fundereturet, abducerentur, consilium ii ineunt quantis maxime collectis viribus novum banum adoriendi, experiendique an serio Hungari antiquam indolem optimatum negligentia ab obitu divi Matthiae semimortuam resumere cogitarint" (VPB, str. 21). Prijevod s latinskoga autor ovoga rada.

15 Antun Vrančıć, Tri spisa, Šime Demo (prir.), Gradska knjižnica Juraj Šižgorić, Šibenik, 2004., str. 35. 
ka bilo smaknuto i zarobljeno. I što je na naš prostor iz boja uteklo, svi su bili poklani i zarobljeni. Vojvoda transilovanski $s$ trideset tisuća ljudi otišao je prema Smederevu, a što je do sada napravio, to ne znamo. A mi, ako Bog da, s našim gospodinom kanimo ući u Bosnu i molimo Boga da dosudi sreću". ${ }^{16}$

Pismo je poslao po novom ugarskom izaslaniku koji je u Mletke stigao u nedjelju 28. kolovoza i doznačio ga istoga dana, kada je predao svoje akreditive. Sanudo je zapisao tada još jednu kratku obavijest, koja je mogla biti dio izaslanikove priče o aktualnim sukobima na turskim granicama, njegov usmeni komentar, kako su Ugri predvođeni Petrom Berislavićem poklali tri tisuće Turaka između rijeke Une i Kupe, daleko od Zagreba dva dana hoda. ${ }^{17}$

$\mathrm{U}$ isto vrijeme krajem kolovoza vijest je dospjela i u Rim. Dočekana je $s$ topovskim plotunima s Anđeoske tvrđave i papinom zahvalnom pobožnošću. Kroničar pape Lava X. Paris de Grassis piše kako se papa silno razveselio kad je čuo da je ugarski kralj potukao nevjernike u bitki, u kojoj je pobijeno dvije tisuće samih konjanika, ne računajući pješaštvo. ${ }^{18}$ Svako od tih kratkih izvješća sadržava po koju novu pojedinost, dragocjenu za oblikovanje jasnijega dojma o samom događaju. Tako se u pismu Antonija Suriana, mletačkoga izaslanika u Budimu, koje je u Veneciju prispjelo 2. rujna, na prvom mjestu ističe izvrsno držanje Petra Berislavića u samoj bitki. Jedino u tom pismu on je posve ispravno tituliran banovim zamjenikom. Prema tom izvješću Berislavić je Turke propustio preko neke velike rijeke, a onda ih $s$ leđa napao s Ivanom Karlovićem. Broj pobijenih protivnika u tom dokumentu već je narastao na $5000 .^{19}$

Domaći kroničari iz XVI. stoljeća nisu također opširni, ali smještaju bitku preciznije u prostor ispod Dubice. Doduše, kronološka tradicija na koju se oslanja Vramec, događaj veže uz 1512. godinu (Due iezere Turkou Peter Berizlo Biskup Wezprimszky i Ban na pole Dubichkom szuoimi Vitezmy i iunaczi poby), ${ }^{20}$ dok je Tomašić u tom smislu prilično određeniji: "Godine Gospodnje 1513., sutri dan nakon Uznesenja Marijina potukoše Turke pod Dubicom ban Petar, biskup vesprimski, i također uzvišeni Mihovil knez slunjski i ostali plemići hrvatski, tako da je

16 M. SANudo, I diarii, liber XVI., str. 673.

17 Isto, str. 671.

18 "Die penultima Augusti, quae fuit mercurii, papa audita victoria per regem Ungariae habita contra infideles Scytas siveTurcas, nam ex eis occisisunt II $\mathrm{m}$ equites exceptis peditibus,illico heri in sero fecit signa laetitiae incastro s.Angeli cum bombardis ut moris est, deinde ipso die hodierno ivit ad ecclesiam de populo ubi missam plenam genuflexus et stolatus audivit quam dixit abbas eius cubicularius" (PARIS DE Grassis, Diarium, Tajni papinski arhiv, ormar XII., 23).

19 M. SAnudo, liber XVII., str. 79.

20 Antun VRAmec, Kronika vezda znovich zpravljena kratka szlouenzkim jezikom, Ljubljana, 1578., str. 53v. 
sve bosansko plemstvo bilo uhvaćeno. Sedam tisuća Turaka pobiše."21

Od svih poznatih pisanih svjedočanstava Tomašićevo je najiscrpnije. Ipak, kad bi se svi do sada poznati podatci o bitki pod Dubicom skupili na jedno mjesto, ne bi se uopće dobila kakva respektabilna građa, relevantnija od napomenutih kroničarskih natuknica. Možda je pisac koristio neke opsežnije kroničarske zapise, bliže vremenu događanja, kao što su oni koji su postojali u samostanu na $\mathrm{Tr}$ satu, dok ih oganj nije sažgao 1628. godine. Ipak, po naravi žanra i prema priči u Zivotopisu nisu mu oni mogli pružiti kakvu opsežniju obavijest osim još kojega imena ili toponima. Za razliku od Tomašićeve, Vramčeve ili drugih obavijesti, uglavnom reduciranih i fragmentarnih, životopisac je svoj prikaz izložio vrlo opsežno. Već sam sažetak može ukazati na potpunu zaokruženost, sugestivnu uvjerljivost priče koja oponira upravo svojom zaokruženošću fragmentarnih povijesnih izvora.

Dakle, nakon što je Berislavić započeo uspješno zaustavljati turske prodore preko granice, Junuz, bosanski sandžakbeg, šalje dvanaest tisuća vojnika $s$ njihovim zapovjednicima preko Vrbasa i Une kako bi ocijenio kane li zaista Ugri s novim banom obnoviti staru ratničku vrlinu. Berislavić na brzinu prikuplja vojsku i pojavljuje se odakle je najmanje očekivan, pređe Savu kod Jasenovca 15. kolovoza na Gospojinu, Turcima $s$ leđa, i utabori se tako da mu bokove štiti Sava $s$ jedne, a Una s druge strane. Turci, koji su u tom trenu opsjedali Blinju, uznemire se i počnu se utvrđivati, da se brane i osiguraju bogat plijen, ali doznavši za jedva tri tisuće banovih vojnika, procijene da je neiskusan. Kako na tako veliki blagdan svoje i ugarske zaštitnice ne htjede započinjati boj, Berislavić u biskupskom ornatu održi svečanu misu na bojnom polju i pritom poticajni govor vojnicima, pa ode na počinak. Po noći se veselilo u turskom taboru, dok je Petrov bio zakriven tišinom. Ujutro rano naredi da vojska objeduje i pripremi se za boj. Osokoli čete sličnim riječima kao i dan ranije tijekom misne propovijedi, pa se obrati Bogorodici zanosnom molitvom, prekriži sebe i vojsku, zazove glasno ime Isusovo tri puta, podbode konje i jurnu u boj. Turci su se branili istom žestinom. Dok je promišljao kako bi ih zbunio, ugleda Bali-vojvodu i započe ga izazivati, jurnu prema njemu i buzdovanom ga snažno mlatnu po glavi. Kada to spaziše, Turci okrenu leđa, a banova ih vojska poče sjeći i zarobljavati. Skupina od četiristo turskih konjanika pobježe preko Save (?). Nju su presreli vojnici nadbiskupa Bakača, koji su kasnili i žurili se iz Čazme. Mnogi se Turci utopiše u vodi. Stotinu i pedeset između zarobljenika, sve uglednih osoba, posla kralju u znak pobjede, a on ih dade odmah javno pogubiti. Ostale razdijeli velikašima i prijateljima.

Imaginarij te priče drži se čvrsto triju polazišta, koja joj osiguravaju dodatnu uvjerljivost: a) različitih dokumenata; b) zemljopisne karte i

21 Ivan Tomašić, "Chronicon breve Regni Croatiae", u: Arkiv za povjestnicu jugoslavensku, (uredio Ivan Kukuljević Sakcinski), knj. 9, Zagreb, 1868., str. 3-34. 
c) povijesno-narativnoga obrasca u prikazivanju kršćanskih pobjeda nad turskom vojskom kod humanističkih historičara.

Ad a). Osim spomenutih kroničarskih podataka o vremenu i mjestu događaja, kao kod Tomašića, pisac je raspolagao i ponekim egzaktnim, za samu bitku sporednim podatkom iz domaćih arhiva, kao što je onaj o Čazmi kao sjedištu Kaptola Zagrebačke biskupije, kojim tada ravna nadbiskup ostrogonski Toma Bakač. Također su djela povjesničara onoga vremena nudila podatke o povijesno važnim osobama, njihovim zaduženjima i kompetencijama, prikazima sličnih situacija. Datiranje je bitke točno i slaže se $s$ Tomašićem, kao i sudjelovanje kneza Mihovila Slunjskog. Uvođenje nekoga od Zrinjskih posve je logično jer su upravo tada ugrožena njihova imanja s glavnom utvrdom po kojoj se i zovu. Pojedini likovi, posebice oni glavni, svakako su te provenijencije. Junuz bega, koji je stupio na dužnost sandžaka upravo 1513. godine, potvrđuju turske kronike, koje objavljuje Leunclavije. ${ }^{22}$ Bali-vojvoda, kao glavni zapovjednik vojske, također može biti iz istoga izvora, ali je u životopisu samo citatni lik, jer se povijesni Davud Bali ${ }^{23} \mathrm{u}$ isto vrijeme ističe u bojevima pod Smederevom kao megdandžija i zapovjednik azapa, zvorničkoga bega. Juraj
Stresemlej (Georgio Stresemley), koji je prema životopisu u bitci predvodio palatinovih dvjesto oklopnika i Ivan Paksy (Joannes Paxy), zapovjednik vojnih jedinica ostrogonskoga nadbiskupa, povijesne su osobe. Prvi od njih mogao je biti u bitki pod Dubicom, jer se njemu dva-tri dana ranije zajedno s Nikolom Sekeljom (Nicolaus Zekel) kralj Vladislav obraća kao jajačkim banovima, ${ }^{24}$ što pisac ne spominje. Ipak se nameće pitanje zašto bi on zapovijedao elitnim palatinovim postrojbama, koje su se inače obično suprotstavljale janjičarskim jedinicama, a rijetko konjici akindžija i zar takve postrojbe nemaju svoga stalnog zapovjednika. Za drugoga je po svemu sudeći to nemoguće tvrditi, ne zato što je u Životopisu tek nakon pobjede krenuo iz Čazme prema Dubici, nego stoga što se tek pedesetak godina kasnije spominje kao zapovjednik vesprimske tvrđave u bojevima s budimskim pašom. ${ }^{25}$ Katalog turskih zapovjednika, koji bi trebao odgovarati onom Tomašićevu podatku o zarobljenoj bosanskoj gospodi u toj bitki, obična je falsifikacija koja iskrivljeno napisanim imenima sugerira vrlo star dokument, zabilježen od kakva tuđinca, a zapravo se radi, makar prema tim imenima i prezimenima, o osobama sumnjiva podrijetla, nemuslimanima i novopečenim konvertitima ili prebjezima, o skupini

22 Johannes Leunclavius, Historiae muslumanae Turcarum, de monumentis ipsarum excerptae, Francfurti, 1591., str. 705-706.

23 Isto, str. 706.

24 Oklevéltár a magyar királyi kegyuri jog történetéhez, Budapest, 1899., str. 85-86.

25 Franciscus Forgachinus de Ghymes, Rerum Hungaricarum sui temporis commentarii, Požun, 1788., str. 57. 
koja bi mogla najprije pripadati najobičnijim akindžijama. ${ }^{26}$

Ad b). Prema prilično uopćenoj slici prostora, približno točnom rasporedu toponima, opisu mikrotoponima i općom podudarnošću s autentičnim dokumentima, čitatelj se može uvjeriti da je prikaz bitke pisan ipak na osnovi nekoga sadržajnijeg predloška. Međutim, takvom dojmu pridonosi posve razvidna uporaba zemljovida, na kome je pisac razvijao vojne operacije, koncentrirajući orijentacijsku točku oko utoka Une u Savu, na domak savskoga otoka, koga danas nema, a prikazuju ga uglavnom svi zemljovidi XVI. i XVII. stoljeća s tvrđavom Jasenovac na sebi. Iz te prostorne perspektive uvedene su ostale zemljopisne odrednice koje tekst spominje. Tu epsku pozornicu markira Pakrac, Velika i Čazma sa sjeveroistoka, a zatvara je Zrinjska gora između Une i Sunje na jugozapadu, u njoj ili odmah uz nju spominju se Dubica, Kostajnica i utvrda Blinja. Pisac i ne zna za Sunju jer je na zemljovidima ona označena imenom od pet slova od kojih je prvo $D$ posljednje $a$, a ostali je dio imena teško čitljiv: Daina, Duman i slično, što je on pročitao kao Drina i tako naveo u svom tekstu. Za pisca je cijeli prostor međuriječja ravnica sa zemljovida na kojoj su naznačene točke daleko bliže nego u stvarnim odnosima, pa su Turci pri opsjedanju Blinje vrlo brzo saznali kako je banova vojska četiri puta brojčano slabija. Njihovo se na brzinu utvrđeno sklonište, u čije su središte stavili plijen i zarobljenike, najednom našao vrlo blizu ušća Une ispred tabora banovih jedinica. Tu je pisac sutra ujutro i započeo bitku smatrajući da je njezino poprište upravo pod Dubicom, kao na tim nepreciznim zemljovidima. Dubica je odatle udaljena dvanaestak kilometara i kontrolirala je prijelaz preko Une, kuda su Turci mogli prijeći s plijenom lakše nego na bilo kojem drugom mjestu.

Kako piše u Životopisu, vojne snage nadbiskupa i kardinala Bakača, predvođene Mihovilom Paksijem, oklijevale su poći iz Čazme s Berislavićem preko Save, bez obzira na njegova pisma i poruke. Tek kada su čuli da je banova pobjeda izvjesna, požurili su se prema bojištu. Takav manevar nije bio izvodiv niti u slučaju da je Čazma bila tri puta bliže, pa je očito da se $\mathrm{Mr}$ navić prepustio epskom maštanju koje je zacijelo oslonio na kakav zemljovid s proizvoljnom predstavom prostora, tim više što jedan takav spominje u posveti Životopisa opatu Draškoviću.

$\mathrm{Na}$ tim zemljovidima Una je često prikazana kao obrambeni limes s tvrđavama koje oplakuju njezine vode, pa se na njima pričinja šira i dublja od drugih ucrtanih rijeka. Izgleda da je piščeva prostorna imaginacija

26 "Skupivši Junuz-beg, bosanski paša, veliku vojsku kojom je zapovijedao Bali vojvoda, vrlo hrabar čovjek s drugim vođama, za ono vrijeme velikoga iskustva i hrabrosti na tim krajinama, među kojima su se isticali: Sklolić Miklouš, Pribig Husein, Jusuf Kokoić, Skender Budelešić, Špirin Safer, Karabaša i Karahusein."

"Conscripto itaque Junusbego Bosnensi Praetore magno exercitu, praepositoque ei Balyvojvoda viro fortissimo, junctis isti aliis ducibus per ea tempora magnae expirientiae ac virtutis in his limitibus, quorum praecipui fuere; Sclolith Miclous, Pribig Husain, Iusuph Kokoich, Skender Buthelesich, Spirin Saffer, Karabasia et Karahusein..." (VPB, str. 21). 
potaknuta tim dojmom držala da je Savu jednostavnije pregaziti, pa je bijeg cijele formacije od četiristo turskih konjanika iz bitke usmjerila na lijevu savsku obalu. Njih su presreli i zarobili spomenuti Bakačevi vojnici koji su se žurili iz Čazme prema bojišnici, nedvojbeno negdje na putu prema Čazmi. Taj nevjerojatni smjer kretanja cjelovite i brojem respektabilne turske vojne formacije, koja nesumnjivo pozna taj prostor, održavao je i pripovjedačevu zamisao da ne dovede na bojišnicu ni nakon bitke vojne snage ostrogonskoga nadbiskupa, da umanji ili marginalizira njihov mogući doprinos i motivira kasnije loše odnose s Berislavićem.

Ad c). Prikaz bitke pod Dubicom u osnovi slijedi obrazac pobjedničkih bitaka s Turcima u humanističkih povjesničara, prema kojima brojno nadmoćna Turska vojska kreće $s$ nakanom da pobijedi i zaustavi nekoga slavnog kršćanskog vojskovođu, a on s prisebnošću duha, koja uvijek prati njegovu hrabrost i ratničku vještinu, u takvim okolnostima pronađe i iskoristi neku taktičku prednost $\mathrm{i}$ nadvlada neprijatelja. Takvu osnovnu fabulativnu strukturu prate uobičajeno isticanje zapovjednika, raspoloženje pred bitku u jednom i drugom taboru, poticajni govori vojnicima, vrlo kratki prikaz bojne srčanosti jedne i druge strane, a zatim opis odlučujućega trenutka u sukobu. Nakon uspješnoga progonjenja neprijatelja, slijede podatci o plijenu, poginulima i slanju zarobljenika kralju na poklon.

Taj fabulativni skelet, koji je često zaodjevan Barletievim pobjedama
Skenderbega i Bonfinijevim prikazima pobjeda Ivana Korvina nad različitim turskim vojskovođama, nosi i priču o bitki pod Dubicom, jamčeći njezinu cjelovitost i zaokruženost.

\section{Mirakularna sastavnica priče}

Autor ga je na osobit način proširio, uključivši u taj obrazac održavanje svečane svete mise na Gospojinu i molitve Bogorodici pred samu bitku. Ta su proširenja zadržala uzvišenost ostalih detalja koji su prepoznatljivi u ranije navedenom sažetku, a motivirani su činjenicom da je vojskovođa istodobno i pobožan biskup. Međutim, tek sa završnom informacijom o poginulima, te nadopune imaju dublji smisao od dimenzioniranja glavnoga lika. Naime, pisac ne ističe broj poginulih Turaka, kao što bi se očekivalo prema spomenutom obrascu, ali samo deset poginulih banovih vojnika, i dakako mnoštvo ranjenih, nakon bitke koja je trajala četiri sata, smatra nebeskim čudom.

"Boj trajaše otprilike četiri sata. Mnoštvo Turaka pogibe od mača, a mnogi u rijekama. Od naših, čudesno je reći, a događaj se ne da objasniti, ako ne božanskom moći, tek je deset poginulih, ipak mnogi su ranjeni. Od zarobljenih, u znak pobjede sto pedeset uglednijih posla ban kralju, određen broj prelatima, velikašima i ostalim prijateljima, svakom prema njegovu položaju. Svima onima koji su dospjeli u kraljeve ruke odrubljena je glava javno na trgu." 27

Spomenuti mirakularni detalj, kojim priča o boju završava, markira Petro-

27 "Duravit proelium ad quatuor horas, Turcarum ingens copia ferro, plures fluviis perierunt. Ex nostris mirum dicta et non nisi divine potentiae referendum factum, vix decem 
vo čudesno ozdravljenje i njegovu posebnu pobožnost prema Bogorodici, koja mu je u jednom ranijem inicijacijskom viđenju obećala djela na čast domovine, ako se zaredi za svećenika. $\mathrm{Na}$ toj razini obredni i molitveni detalji imaju ulogu provođenja misaone niti o djelovanju nebeske providnosti kao odgovora na pobožne molitve. Ta značajka izrazito hagiografske i mirakularne provenijencije, netipične za Vrančića, upućuje ponovo na Mrnavićevo autorstvo.

\section{Podudarnost $s$ Istvanffyjevim narativom iz Ugarske povijesti}

U cijelom tekstu, koji prikazuje zbivanja od početka turskoga pohoda do njegova poraznog kraja, pokazuju se stanovite neujednačenosti perspektiva i sadržaja koje se međusobno isključuju. Na samom početku pisac kazuje kako su turske snage prešle Vrbas i Unu i upale u krajeve između Une i Kupe, ističući da je Una granica između Bosne i Hrvatske. Kratka digresija o razgraničenju uvodi u izlaganje posve novu vremensku perspektivu koja, naznačuje i aktualizira pripovjedačevo nasuprot fabulativnom vremenu u kome se odvijaju događaji. Ni u najvećoj Tvrtkovoj ekspanziji Una i Pounje nisu bili u sastavu Bosne. U Berislavićevo vrijeme spomenute granice bile su daleko istočnije, svakako iza rijeke Vrbasa i s onu stranu Jajca, koje je doduše bilo u stalnoj opasnosti. Obrambeni limes na Uni istrajavao je skoro cijelo XVI. stoljeće u neprestanim bitkama za pojedine utvrde, od kojih je Bihać pao posljednji 1592. godine. Takva je tvrdnja mogla biti izrečena stotinjak ili više godina kasnije kada su Turci ovladali starom komunikacijom koja je od Skradina i Knina preko Bihaća išla lijevom obalom Une, a bojevi se s njima premjestili još zapadnije. Premda se u cjelini o bitki pod Dubicom, kao i u cijelom Životopisu, zamjećuje nekoliko jasnih signala prelamanja vremenskih perspektiva, uglavnom priloške naravi ("za ono vrijeme" ili "sve do danas"), upravo spomenuta suprotstavljenost semantizira njihovu dublju distancu od pripovjedačeve vremenske pozicije, što favorizira Mrnavića kao autora.

Druga, svakako ključna neusuglašenost, u samoj je fabuli, izrečena je tvrdnja o prelasku turskih snaga preko Une na početku pohoda u odnosu na položaj Berislavićeva zauzetog položaja između dviju rijeka, koja im je zapriječila jedini mogući prijelaz u povratku s plijenom preko Save kod Jasenovca, izgleda zbunjujuće čak i onda kada bi se do kraja uvažavala ona nakana samoga pohoda s početka priče, prema kojoj je vrlo snažna formacija od 12.000 Turaka krenula $\mathrm{da}$ ispita stvarne banove borbene sposobnosti i možebitne ugarske nakane da obnove staru i izgubljenu ratničku vrlinu: "Osvanuo je 15. kolovoza, sveti dan Bogorodičina uznesenja na nebo, kada je Petar na spomenutoj ravnici gdje utječe Una u Savu postavio tabor tako da bokovi tabora budu s dvije strane zaštićeni i da oduzme

desiderati, complures tamen faucii. Ex captivis centum quiquaginta nobiliores in signum victoriae regi banus transmisit, ad praelatos optimates, ceterosque amicos, uniquique pro sua conditione, certum numerum. Quicumque ad regias manus pervenerumt, ii omnes publice in foro capite plexi sunt" (VPB, str. 28-29). 
mogućnost neprijatelju ako bi se namjeravao povući." 28

Zar se Turci nisu mogli povući preko Une otkud su i došli ili povlačeći se prema nekom poznatom prijelazu ispod Dubice ili Kostajnice odnosno ispod Novoga, kada su vidjeli da je bitka izgubljena, što bi i bilo u panici izvjesnoga poraza posve vjerojatno i psihološki opravdano?! Kamo bi to oni nastavili prelaskom preko Save na njezinu lijevu obali?! Upravo je stoga ta neusuglašenost u samom fabulativnom izlaganju mogla nastati pod uplivom nekoga autoritativnog predloška čije obavijesti pisac Životopisa nije htio ignorirati.

Poznate povijesti iz XVI. stoljeća i ne spominju tu bitku, a sačuvane kronike i dokumenti točno je ne ubiciraju. $\mathrm{Ni}$ jedan povijesni izvor iz vremena u kome je živio i djelovao Antun Vrančić ne smješta je na ušće Une u Savu, a teško je pretpostaviti da bi je iz prije spomenutih razloga on sam na to mjesto ubicirao. Međutim, Istvanffyjeva Historia Regni Hungariae, koja je zamišljena u 36 knjiga, obuhvaća događaje od smrti kralja Matijaša do 1606. godine, bitku s Turcima iz 1513. godine smješta upravo na ušće Une, isto kao i Životopis Petra Berislavića, ali s izrazitijim strateškim i orijentacijskim nedoumicama: "I čim je došao u pokrajinu, brzo mu je sreća pružila priliku da pokaže svoju vrlinu i hrabrost. Dakle, nakon što su Turci u velikom broju prešli Savu, na sve strane opljačkali i ognjem i mačem opustošili kraj smješten između rijeka Save i Une (koju su, kako neki smatraju, preci nazvali Valdan), skupivši čete, koliko je u žurbi i uzbuni mogao, napao ih je nedaleko od Dubičkog grada i utvrde gdje Una u Savu utječe i nakon što je znamenita bitka okončana, neprijatelje je razbio i natjerao u bijeg, one koji su bježali na dugo i široko progonio, više od dvije tisuće pobio, i nakon što je izuzetno veliki broj zarobljen i mnogo veći broj u Savi utopljen, a malo se njih plivajući izbavilo, izgledalo je da su tako neprijatelji bili obilato kažnjeni zbog svoje drskosti i podlosti i narušenog primirja. I takvim istrebljenjem preplašeni, također u isto doba kakogod silom primirja prisiljeni, držali su se podalje od pohoda i pljačkanja."29

28 "Dies iluxerat decima Kalendarum Septembris assumptae Deisparae in coelum sacra, quando Petrus in praesatam planitiem Unnae Savique confluente castra locat ut et castrorum latera ita duabus ex partibus essent munitiora et retrocedenti hosti copiam aufferet" (VPB, str. 23).

29 "Et quum in provintia veniset, brevi occasionem virtutis fortitudinisque suae declarande fortuna ei obtulit. Nam, cum Turcae magno numero Savum traiecissent et regionem inter Savum et Hunnam fluvios (hunc a priscis Valdanum olim appelatum fuisse quidam putant) adiacentem passim popularentur ac ferro et igne vastarent. Colectis, quantis in re subitanea et tumultuaria potuit, copiis eos non procul ab arce et oppido Dubicensi ubi Hunna in Savum influit, adortus est, insignique edita pugna hostes fudit atque fugavit, et fugientes longe lateque persequutus, amplius duo millia eorum interfecit, captis quamplurimis et multo maxima parte in Savum demersa paucis natando evadentibus ita ut hostes audatiae perfidiaeque suae et violatorum induciarum cumulatas poenas dedisse viderentur. Atque hac strage perculsi, simul etiam qualicumque induciarum vi coerciti, excursionibus et praedis agendis aliquamdiu abstinuerunt" (Nikolaus Istvanffius, Historia Regni Hungariae, post obitum gloriosissimi Matthiae Corvini regis Historiarum de rebus Ungaricis, liber IV., Köln, 1622., str. 38). 
Prema tome turski je pohod u međuriječje stigao s lijeve obale Save iza Unina ušća, što svakako podrazumijeva još jedan prijašnji prelazak Save iz Bosne u Slavoniju. Ta bi neobična taktika trebala biti ponovljena i u povratku, da se banova vojska nije ispriječila i razbila Turke upravo ispred toga prijelaza, na što nedvojbeno upućuju brojni Turci koji su se u Savi utopili, bježeći pred progoniteljima. Očito je Istvanffy sve događaje usmjerio na glavne smjerove turskih prodora iz njegova vremena, koji su postali aktualni sa Sulejmanovim osvajanjima. Bliskost Istvanffyjeva teksta i Životopisa posve je izvjesna u nekoliko sadržajno važnih točaka:

1. U oba teksta ban je iznenađen turskim napadom i na brzinu prikuplja vojsku, što je u koliziji s autentičnim povijesnim dokumentima (Vidi bilješke s početka). Za razliku od Istvanffyjeva teksta, iznenađenje i obrambena nespremnost motivirani su dodatno u Životopisu banovom izmišljenom odsutnošću u donjim krajevima $\mathrm{Hr}$ vatske, što zapravo upućuje na epski postupak dramatizacije trenutka.

2. I u jednom i u drugom tekstu očiti su nelogični smjerovi turskoga taktičkog napredovanja. Istvanffyjevi prelasci Save u dolasku i u nakani povratka, u Životopisu su dijelom korigirani prelaskom Une na početku, a u povratku na bijeg dijela turskih konjanika u vrijeme bitke i mali broj plivača nakon poraza.

3. Mikroprostor na kome je bitka započela u oba je teksta isti, ali je pisac Životopisa tom položaju nastojao dati strateško i taktičko obrazloženje u zaštiti bokova banove malobrojnije vojske vodama Save i Une.
4. Nakon poraza Turci se ne usuđuju ponoviti slične napadaje. Taj podatak kojim je Istvanffy zasvodio svoj narativ o Berislavićevoj pobjedi pisac je Životopisa prenamijenio na završetak svoga domišljenog uvodnog dijela o nizu banovih pobjeda kojima je obuzdao tursku napadačku drskost. Istom tvrdnjom motivirao je banovu odsutnost i iznenađenje njihovim snažnim napadom.

5. Ni jedan ni drugi tekst ne osvrće se na sudbinu bogatoga turskog plijena, što je inače redovit detalj u sličnim izvješćima iz toga vremena.

Sve to upućuje da je piscu Životopisa Istvanffyjev ulomak poslužio kao predložak za opsežni prikaz bitke pod Dubicom. Prema tome, autor toga dijela teksta nije mogao biti nitko drugi nego Ivan Tomko Mrnavić. Premda je Ugarska povijest objavljena dvije godine kasnije od Vita Petri Berislavi, Mrnavić ju je nedvojbeno poznavao, makar one njezine rijetke i malobrojne dijelove koji se odnose na njegova junaka i koji su mu mogli poslužiti kao građa koju je on koristio za Životopis. Na to dovoljno upućuje poduža prepiska s njezinim priređivačem Jurjem Draškovićem, Istvanffyjevim unukom, na koju se Mrnavić u posveti referira i čiji je grb dao otisnuti na naslovnici. Posve je jasno iz njegova kratkog osvrta da on znade kako među njezinim sadržajima nema mnogo više podataka o Berislaviću od citiranoga odlomka, pa svoje završeno djelo nudi Draškoviću kao moguću nadopunu Istvanffyjeve Povijesti, što bi mogao biti i jedan od razloga da se držao bez većih preoblika njegova narativa o bitki pod Dubicom, posebice u njezinoj točnijoj ubikaciji. 


\section{Tehnika završetka priče u stilu epideiktičkoga govora}

Prikazom dubičke bitke, njezina mistično proviđena ishoda, u kome su ispunjena očekivanja i polučena slava u svijetu i kod svojih, završen je onaj krešendo i očekivanje u Životopisu koji mu je osiguravao dinamičan slijed. Nakon toga bilo je teško nastaviti u istom registru. Ban je svojom vojskom ponovo vratio makar na tren vrijeme velikih junaka i vrjednota Matijaševa vremena, pa se ni on nije mogao više razvijati ili pisac nije imao ni dovoljno ideja ni podataka. Stoga je svom junaku osigurao divljenje žitelja kraljevstva, koji su u njemu gledali nebesku nadnaravnu pojavu i jedinu osobu koja Ugarsku može podignuti iz ruševina. Završetak priče morao je ići u tom smjeru kako bi se zasvodila sama epizoda i disperziralo žarište pripovijedanja, osvjetljenjem reakcija kod kuće i u svijetu.

Potvrdu velikoga oduševljenja zbog banove pobjede pisac Životopisa prepoznaje u natpisima kao što je onaj na skradinskoj tvrđavi "Krist pobjeđuje, Krist kraljuje, Krist upravlja! Kralj Vladislav." ${ }^{30}$ Ili slična sadržaja na bribirskoj zbornoj crkvi i kninskoj katedrali, koji su se tada uklesavali po javnim građevinama. Osim toga pisca nitko takve grafite nije nikad spomenuo niti vidio. Zanimljivo je da su svi navedeni primjeri iz šibenskoga zaleđa koje je vrlo brzo palo pod Turke. Navedeni slogan kao osobit grafit može se naći na izrađevinama od plemenitih metala gotič- ke stilizacije iz tog vremena, najčešće na novcu. Od XIV. do XVI. stoljeća zlatnici francuskih kraljeva isključivo rabe tu devizu. Međutim, da je tkogod takve podsjetnike pravio u nesigurnim prostorima i vremenima sve češćih turskih prodora, posve je teško povjerovati. Kninska biskupija pravno ne postoji petnaestak godina prije same bitke pod Dubicom. Tobožnja inačica spomenutoga natpisa upravo u kninskoj prvostolnici, "koje se nije vidjelo", kako upućuje Životopis "prije nego su Turci od njezina materijala počeli praviti svoje građevine", dovoljno govori o vjerodostojnosti toga podatka. Međutim, spomenuta turska izgradnja Knina, koja se mogla odvijati tek kad je cijelo šire okružje bilo podloženo, i kad je grad nakon 1580. godine postao središte sandžaka, ${ }^{31}$ upućuje jasnije i na fikcionalnost te cijele kratke priče i na pripovjednu poziciju, zauzetu poslije Vrančićeve smrti.

Cjeline slične kondicije, duhovita predanja ili anegdote susreću se u istoj ulozi završetka pojedinih izlaganja tijekom cijeloga Životopisa. Sadržaji su im redovito uvjerljivi i fikcionalni kao i u završstku pripovijedanja o bitki na Dubičkom polju. Ipak, možda je u tome najdalje otišao navodeći da je papa Leon X. na Božić te 1513. godine nagradio Petra posvećenim mačem i potkapom, darom koji se samo kraljevima dodjeljuje. Kao argument naveo je podatak da se taj mač čuva još za njegova vremena kod rođaka Statilića. U dnevniku pape Leona X. spominje se da je u to vrijeme, neko-

30 "Christus vincit, Christus regnat, Christus imperat! Rex Vladislavius" (VPB, str. 29).

31 Vjekoslav Klaić, "Knin za turskog vladanja", u: Vjesnik Arheološkog muzeja u Zagrebu, Vol. 15, No. 1, Zagreb, 1928., str. 257-262. 
liko dana prije Božića papa poslao gladium et pilleum engleskom kralju Henriku, a ne nekomu drugomu. Je li taj podatak pisac povezao sa svojim junakom ili ga je jednostavno izmislio u svojoj gorljivosti da Berislavića što više pohvali, posve je svejedno. Budući da isti izvor spominje Berislavića i njegovu pobjedu pod Dubicom koja je u Rimu odjeknula u zvonjavi zvona, pucanju topova i u papinoj zahvalnoj pobožnosti, teško da bi De Grassis prešutio takvu čast i nagradu koju je prema Životopisu motivirala upravo spomenuta dubička epopeja. Svakako je taj općeprihvaćeni podatak, prvi put spomenut u Životopisu, uobličen kao svojevrsno zavičajno predanje koje upravo tim svojim oblikom i formulacijom da se mač "još i sad čuva" jamči duboku prošlost u odnosu na trenutak pripovijedanja, isključujući autorstvo mladoga Vrančića.

\section{Zaključak}

Pisac je Životopisa Petra Berislavića vrhunac uspjeha glavnoga junaka povezao $s$ čuvenom pobjedom nad Turcima kod Dubice 16. kolovoza 1513. posvetivši joj desetak stranica Životopisa. Priča o toj pobjedi može se izdvojiti iz konteksta kao zasebno komponirana cjelina koja i time naglašava ključni događaj u postizanju osobne slave glavnoga junaka i opravdanje dostignutih društvenih časti. Međutim, njezina opsežnost i zaokruženost, koja probija tradicionalni oblik životopisa, istodobno je suprotstavljena fragmentarnosti i kratkoći povijesnih podataka o istom događaju. Premda se oslanja na dva poznata povijesna izvora, cijela je priča literarna rekonstrukcija povijesnih okolnosti i doga- đaja, utemeljenih više na kvalitetnim motivacijama nego na autentičnim činjenicama. Priča se razvija prema obrascu humanističkih prikaza Hunjadijevih pobjeda nad Turcima u Bonfinija ili onih Skenderbegovih u Barletija. Neusklađenost vremena i prostora ukazuje da se autor snažno oslanjao na onodobne neprecizne zemljovide. Točnost datuma bitke pisac je izvadio iz Tomašićeve Kronike, čije je obavijesti rabio još na nekim mjestima u Životopisu, a opis same bitke oslonio je na Istvanffyjev opis istoga

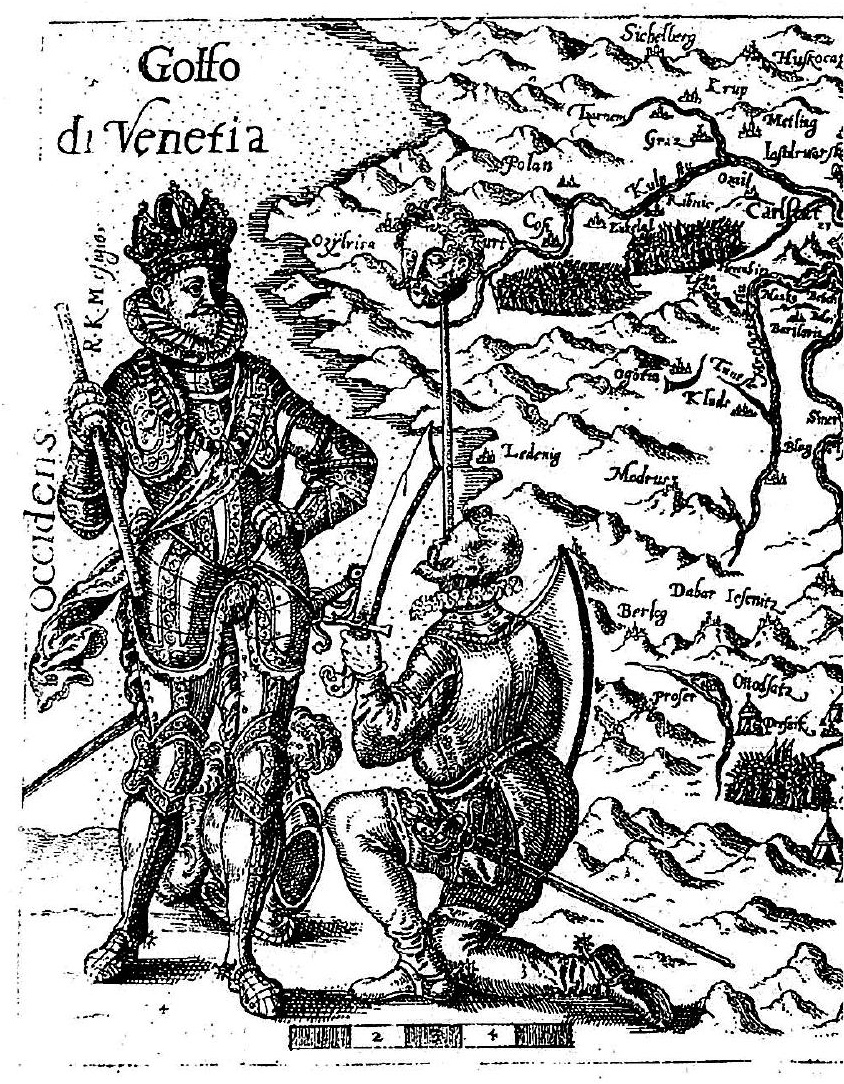


događaja u njegovoj Ugarskoj povijesti. Te utvrđene činjenice posve jasno anuliraju Fortisove optužbe, isključuju autorstvo Antuna Vrančića i za tih desetak stranica teksta potvrđuju Mrnavića kao jedinoga autentičnog pisca Životopisa.

Prikazom dubičke bitke i njezina mistično proviđena ishoda, po kome je poginulo samo nekoliko banovih vojnika, uspjelo je piscu prikazati junaka koji je makar na trenutak vratio slavu Matijaševa vremena. Stoga mu je osi- gurao divljenje žitelja kraljevstva, koji su počeli uklesavati na javnim mjestima Petrovo ime s usklicima svoga oduševljenja, i papin dar, mač s potkapom, kao potvrdu odjeka njegova uspjeha u kršćanskom svijetu. Dakako, sve je to piščeva fikcija, pohvalni diskurs u kome su pojedine naznake vremena odredile točku pripovijedanja na dalekoj distanci, ne samo od fabulativnoga vremena, nego i od smrti Antuna Vrančića.

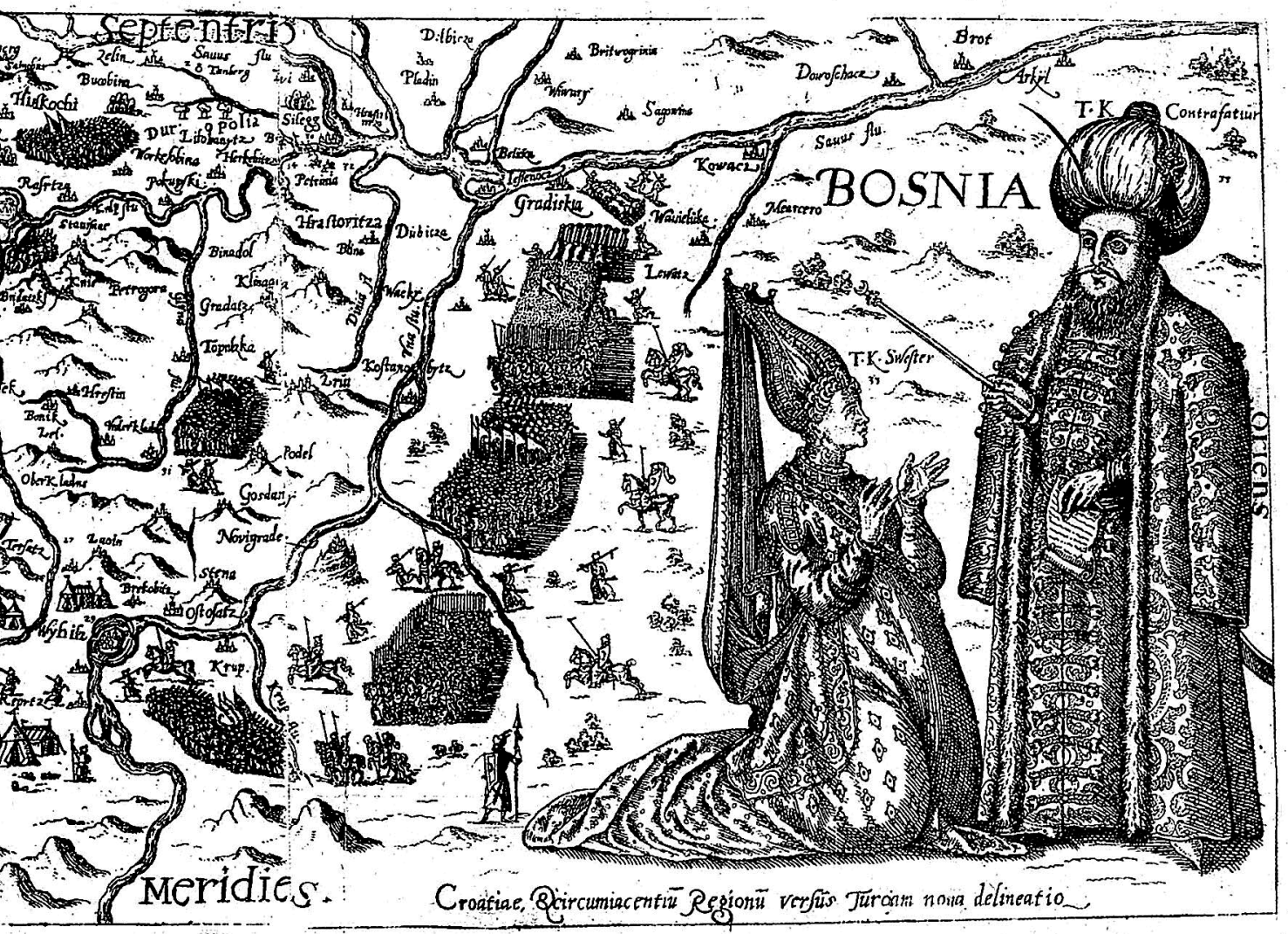

Zemljovid Hrvatske s okolnim krajevima Gerarda de Jode iz 1595. godine 


\section{The narrative on the battle of Dubica from Petar Berislavic's Vita is a fictional story}

\section{Summary}

The author relates the peak of Petar's success to the famous victory over Ottomans near Dubica on 16 August 1513 and devotes to it some dozen pages of the Vita. The story on the victory may be put apart from the context as a self-enclosed whole that emphasizes a key event in a glorified life of the hero, a justification of the social honors and achievements. However, its length and completeness, which goes beyond traditional forms of vita, is also opposed to the fragmented and circumstantial nature of the data concerning the actual historical event. Despite its reliance on two known historical sources, the entire story is a literary reconstruction of historical developments and is based more on motivational guesses than on authentic or empirical facts. The story unfolds after the model of historical representations of Hunyadi's victories over Ottomans by Bonfini or of Skanderbeg's by Barleti. Discrepancies between space and time indicate a chronotopic construction of the story based on the imprecise depictions of the time. The author has derived the date of the victory from a chronicle by Tomasic, which he used on several occasions in the Vita, and the very description of the battle follows Istvanffy's account in his Hungarian Histories. Such established correlations undermine the allegation by Fortis, hence, while excluding Vrancic, they confirm Mrnavic as the only authentic author of the Vita.

By presenting the battle at Dubica and its outcome as a result of divine providence, with only ten loss in life among Ban's soldiers, the author has managed to depict a hero who has succeeded to revive to an extent the glory of Matijas's time. This has secured his glory among the population of the kingdom, who started carving Petar's name (with exclamation marks) over the city; and it has also secured him a Pope's gift, an embellished sword, as a confirmation of his standing in the Christian world. Of course, this is all just a writer's fiction, an epideictic discourse in which significations of time have determined the standpoint of narration from a long distance not only in the sense of narrative time, but also of Antun Vrancic's death.

Keywords: fiction, narrative, falsification, plagiat, Mrnavic, Vrancic, Berislavic, Dubica. 